\title{
Analysis Of Factors That Influence Good Corporate Governance On Earnings Management In Manufacturing Company Listed In Indonesia Stock Exchange
}

\author{
Elok Dwi Vidiyastutik $^{1}{ }^{*}$, Joni Hendra ${ }^{2}$ \\ 1,2 Department of Accountancy, Faculty of Economics, Panca Marga University, Probolinggo 67271, Indonesia
}

\section{A R T I C L E I N F O}

\section{Article history:}

Received 12 February 2020

Received in revised form

29 March 2020

Accepted 18 April 2020

Available online 30 May 2020

\section{Keywords}

Managerial Ownership, Board of Commissioners, Audit Committee, Audit Quality, Earnings

Management

\section{A B S T R A C. T}

The consistent implementation of good corporate governance based on fairness, transparency, and accountability is proven to improve the quality of financial statements. This study aims to determine the influence of indicators of good corporate governance indicators to earnings management in Manufacturing Companies listed in Indonesia Stock Exchange (IDX). The sampling method is porposive samling by taking a sample of 30 manufacturing companies in the consumer goods industry sector which publishes annual report complete year 2014-2018. Data analysis method used in this study is multiple linear regression analysis with the help of SPSS 22.0 program. Previously tested the classical assumptions first. The classical assumption test consisted of normality test, multicolinearity test, heteroscedasticity test, and autocorrelation test. The results showed that simultaneously and partially, managerial ownership, composition of board of commissioner, audit committee and audit quality of KAP size have a positive effect on earnings management.Variable composition of board of commissioner has the most dominant influence to earnings management, shown by value of Standardized efficients Beta 0,303 bigger of the value of Standardized Coefficients Beta of other independent variables.

\footnotetext{
* Corresponding author.

E-mail addresses: elokdwi23@gmail.com (Elok Dwi Vidiyastutik)
} 


\section{Introduction}

The information provided by manager sometimes not in accordance with the condition of a corporation that indeed. This condition caused by information that is not symmetrical or asymmetry information. Asymmetry between management with the land owners company can provide opportunities for manager to do manipulation of the company performance made for their own interest such companies and can harm the shareholders or the investors .Information that was often the target of engineering the management is the information on the profit financial report.

The very act of opportunist is done with the process of selecting an accounting policy as a result of certain so that of a company profit can be arranged, raised or lowered in conformity with the wish. Behavior management in order to profit in the first semester with it the forbidden cravings any means make this arrangement in accordance entrusted bakrie sumatra plantation tbk known by these terms in connection with the management (spider does not permit the report also showed earnings management). Report also showed earnings management happens when the management of the use of certain decisions in the reporting and in the preparation of financial transaksi-transaksi that converts a financial report what happened. It is purpose in order to mislead between stakeholders including to weed out frivolous candidacies of the condition of the economic performance the company most solemnly i tell you, as well as to affect the low level of income to operate the controls of accounting in which the contractual constraints did the desired investment growth figure out cases have been reported.

The very act of opportunist is done with the process of selecting certain accounting policy of a company profit can be set so that, raised or lowered in conformity with the wish .Behavior management to set on his custom profit are known to the term profit (management earnings management). Management earnings management occurs when using certain decisions in financial reporting and the formulation of financial report transactions either that converts. It is purpose to mislead the stakeholders of the condition of the company indeed economic performance, as well as to affect income contractual arrangement control accounting figures who were declared to be.

Profit a management action created a small number of cases of the scandals of the reporting accounting in which the widely sub districts were known as, its industrial activity among others enron, merck, world com, healthsouth, palamalat, tyco and xerox ( razek, 2012 ).In indonesia they took the form of a small number of cases that are detected by as manipulation in a financial, such as PT Lippo tbk and PT .Kimia Farma tbk. This phenomenon indicates that the occurrence of a financial scandal is the failure of a financial report what happened to meet the needs of users will get more information things in the financial report .One of the causes of the case of move on from the scandal is the lack of observation will implement good corporate governance (Kompas daily news in Jakarta, 21 November 2002).

The existence of the principle of good corporate governance that is expected to minimize the performance engineering activities that resulted in the financial report did not describe the fundamental value of the real company (Action marked Up financial statements). Some of the research on the mechanisms used in good corporate governance that affects profit in the first semester in connection with the management has also been carried out and it was found a wide range of results.This research build on the research ningsapiti in the year 2013, but have several differences in pt pgn promised to supply years of research that different structures and the subject of study .Research ningsapiti sought to find out to several manufacturing companies in the year 2009-2011, while this research used data on several manufacturing companies in the year 2014-2018 in order to be more up date.In addition, in this research is added one the independent variable mortgage loan dubbed kpr ekspres managerial muamalat ran into financial difficulties as a single proxy good corporate governance .Managerial mortgage loan dubbed kpr ekspres and taken up in this research as the number of shares owned by meanwhile the housing complex manager assumed to be able have an impact on the act of meanwhile the housing complex manager in decision making and also in its financial statement is the company

Research conducted by Hendra J, Koesharjono, and Priantono using data from manufacturing companies in 2013-2017 in 2018 analyzed the effect of the proportion of independent commissioners on earnings management and stated that the proportion of independent commissioners as a proxy for good corporate governance that had no effect on profit management. This research differs from Retno and Priantinah's (2012) research which states that the proportion of the board of commissioners has a significant effect on earnings management. Research on the influence of the composition of the audit committee as a proxy for good corporate governance has also been carried out by several previous studies.

Qomariyah's research in 2008 analyzed the effect of the proportion of independent board of commissioners on earnings management and stated that the proportion of the board of commissioners as one of the proxy of good corporate governance has no effect on profit management. This research differs 
from research by Ratna and Wardhani (2012) which states that the proportion of board of commissioner has a significant effect on earnings management. Research on the influence of audit committee composition as one of the proxy of good corporate governance has also been done by some previous research.

Indonesia is the state of being in countries with weak investor protection, so it has a high profit management practices. The built in corporate governance must be able to protect hak-hak shareholders the right to ( 1 ) ensure the safety of the registration ( 2 ) divert or move shares they owned ( 3 ) be relevant information about the company periodically and orderly ( 4 ) involved and to vote in the gms ( 5 ) selecting members of the board of commissioners ( 6 ) obtain the corporate profits.

The principles in implementing good corporate governance proposed by the General Guidelines for Good Governance in Indonesia (2006: 5-7) consist of; (1) transparency, (2) accountability, (3) responsibility, (4) independence, (5) fairness and equality

Managerial ownership is a condition in which the manager owns the company's shares or in other words the manager as well as the shareholder of the company (Tarigan, Josua and Christiawan, 2007: 2). Theoretically when management ownership is low, the incentives for possible opportunistic behavior of managers will increase. Management's ownership of the company's shares is seen as harmonizing potential differences of interests between outside shareholders and management (Jansen and Meckling, 1976: 339 in Pujiati 2015: 38). So the problem of assumed keagenen will be lost if a manager is also at the same time as an owner (Pujiati 2015: 38). Managerial ownership is measured on the basis of the percentage of outstanding shares owned by the management of all outstanding share capital of the company and measured using the ratio scale. The calculation of managerial ownership is as follows Managerial ownership is calculated by the following formula (Kartika, 2005: 113):

(Hayati and Gusnardi, 2012: 370). In order to ensure the implementation of good corporate governance, members of the board of commissioners who have integrity, ability are not legally defective and have no business relationship or other relationship with the controlling shareholder (majority) either directly or indirectly. The board of commissioners is often considered to be of no benefit, this can be seen in the fact that many members of the board of commissioners have no capacity and can not demonstrate their independence.

The composition of the board of commissioners (Board of Commissioners) is a membership composition consisting of outside commissioners and commissioners from within the company. Independent Commissioners are members of the board of commissioners who have no financial, management, share ownership and / or family relationships with other members of the board of commissioners, directors and / or controlling shareholders or other relationships that may affect their ability to act independently (Puspitasari and Ernawati, 2010 : 193-194). According to Hayati and Gusnardi (2015: 372) the proportion of independent board of commissioners is measured by percentage of the number of independent board members of the total number of the company's board of commissioners and measured by the ratio scale.

The audit committee is in charge of assisting the board of commissioners by providing independent professional opinion to improve the quality of work and to reduce the deviation of the company's management (Surya and Yustiavanda, 2006: 146). The existence of the audit committee is very important for the management of the company. Audit committee is a new component in the company's control system. In addition, audit committee is considered as a liaison between shareholders and board of commissioners with the management in handling the problem of control.

Based on the Circular Letter of BEJ, SE-008 / BEJ / 12-2001 in Kumala (2014: 24), the membership of the audit committee consists of at least three persons including the chair of the audit committee. Members of this committee who are from commissioners are only one person, Committee members who are from the commissioner are independent commissioners of listed companies as well as chairman of the audit committee. Other members who are not independent commissioners must be independent external parties with minimum accounting and financial skills.

The composition of the audit committee is measured using an external audit committee percentage indicator of all audit committee members (I Guna and Herawati (2010: 61)).

The size of KAP is the size of the audit firm. In delivering accurate and reliable financial statements, a company would need the services of a Public Accounting Firm. In addition to ensuring the credibility of the financial statements, the company will also tend to use the services of Public Accounting Firm is large and have a good name. This big public accounting firm is often called the big four. BIG 4 for large Public accounting firm

and Non BIG 4 for small Public accounting firm.. Auditors including BIG 4 have higher audit quality as their focus on name reputation protection. 
In addition, companies that use the services of KAP BIG 4 tend to be more trusted when compared with companies that use the services of KAP Non BIG 4. Category KAP BIG 4. In this study the audit firm size uses dummy variables, value 1 if the firm is audited by BIG 4 Auditor and 0 if audited with others (Gerayli et al, 2011).

According Sulistyanto (2008: 48) earnings management is "Efforts of corporate managers to intervene or influence the information in the financial statements with the aim to know the stakeholders who want to know the performance and condition of the company. According to Subramanyam and Wild (2010: 131) "Profit cosmetic management is the result of freedom in accrual accounting applications that may occur". Thus, earnings management can be interpreted as an action of earnings management that affects reported profits and provide false economic benefits to the company, so that in the long run it will be very disturbing and even harm the company. According Sugiri (1998) in Ma'ruf (2006: 17) there are 2 definitions of earnings management (earnings management) namely: Earnings management in this case is only related to the selection of accounting methods. Earnings management in this narrow sense is defined as a management behavior to "play" with the discretionary accruals component in determining the amount of earnings.

Broad definition; Earnings management is the actions of managers to increase (decrease) current reported profits on a unit in which managers are responsible, without causing an increase (decrease) of the unit's long-term economic profitability.

Earnings management as an intervention with a specific purpose to the company's financial reporting process is done by the manager intentionally to gain personal gain. Managers malakukan opportunistic actions in the preparation of transactions with the selection of accounting policies to change financial statements, thus misleading the owners of the company about the economic performance of the company and to influence the results associated with the contract depending on the accounting figures reported.

\section{Methods}

Jenis The type of this research is comparative causal research, that is; research showing the direction of the relationship between independent variables and dependent variables, in addition to measuring the strength of the relationship (Sangadji and Sopiah, 2010: 22). The object of research which become population in this research is manufacturing company which listed in Bursa Efek Indonesia (BEI) with period of year 2014-2018. While sampling technique in this research is done by using purposive sampling method, that is determination of sample based on suitability of certain characteristic and criterion (Erlina, 2008: 75). Based on the characteristics of sampling above, the research samples obtained by 30 companies.

Data analysis method used in this study is multiple linear regression analysis with the help of SPSS 22.0 program. Previously tested the classical assumptions first. The classical assumption test consisted of normality test, multicolinearity test, heteroscedasticity test, and autocorrelation test. The formulas of multiple linear regression (multiple linear regresion) are:

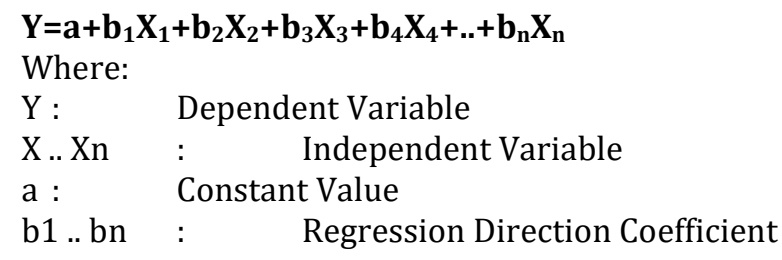

\section{Result And Discussion}

In general, descriptive statistics of research variables used, indicating that the minimum value of managerial ownership of 0.21 and the maximum value of 0.96 from PT. Sekar Laut. The highest commissioner value of 0.80 is owned by PT. Unilever, the highest audit committee value is 0.66 is owned by many companies, among others, PT. Ades, PT. Mayora and PT. Sari Roti. The highest audit quality score of 1 and the last highest profit management value of 4.699 .

Managerial ownership is measured based on the\% (percentage) of the outstanding shares owned by the management of all outstanding share capital of the company and measured using the ratio scale. From the calculation of the proportion of managerial ownership shows the average Managerial Ownership in 2014 amounted to 0.71 , the year 2015 of 0.69 , the year 2016 of 0.71 , the year 2017 of 0.69 and the year 2018 amounted to 0.71 . 
The average development of managerial ownership in $2014-2018$, can be seen in the following figure:

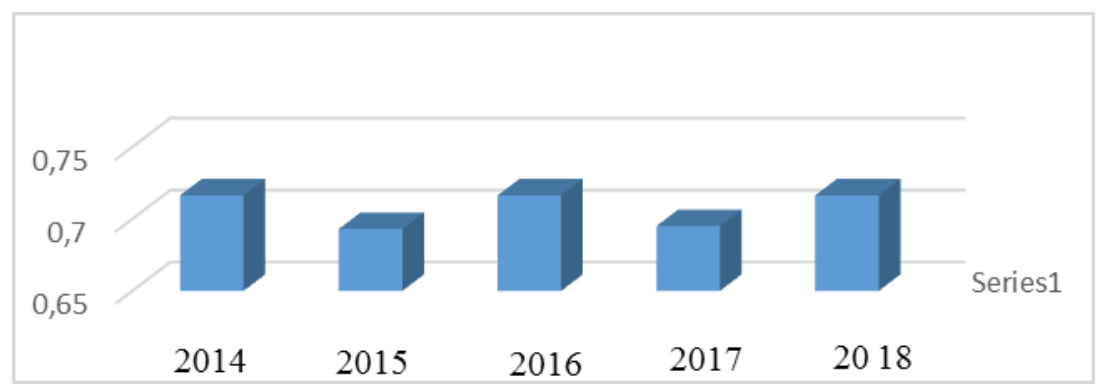

Figurre 1. Managerial Ownership Chart Year 2014-2018

Source: Data Processed 2019

The proportion of the board of commissioners is measured based on\% (percentage) of the number of independent board members of the total number of the company's board of commissioners and is measured by the ratio scale. Of the 30 samples used showed the average composition of the board of commissioners in 2018 of $0.37,2017$ of $0.36,2016$ by 0.35 , the year 2015 of 0.35 and the year 2014 amounted to 0.37 . The average development of the composition of the board of commissioners in 20142018 , can be seen in the picture below.

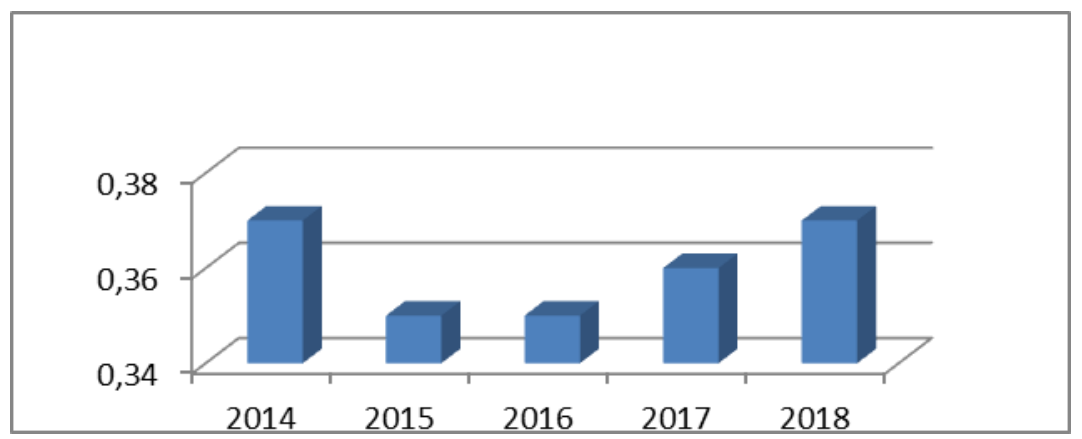

Figure 2 . Composition of the Board of Commissioners Chart Year 2014-2018

Source : Data Processed 2019

The composition of the audit committee is measured using an external audit committee percentage indicator of all committee members. Of the 30 samples used indicate the average audit committee in 2018 of $0.63,2017$ of 0.64 , the year 2016 of 0.64 , the year 2015 of 0.64 and the year 2014 amounted to 0.63 . The average development of the composition of the board of commissioners in $2014-2018$, appears as follows:

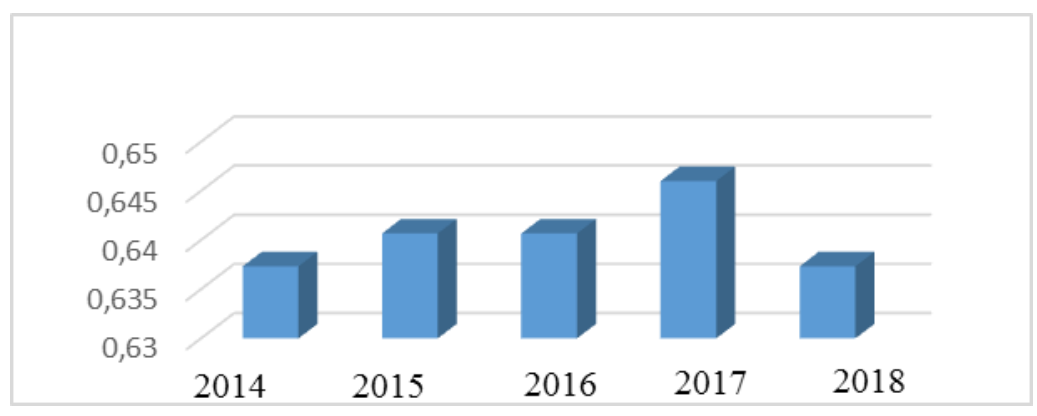

Figure 3 . Composition of the audit committee Chart Year 2014-2018

Source : Data Processed 2019 
The better the services of public accountant firm then the better the quality of the financial audit report generated. In this study audit quality uses dummy variable, value 1 if the company is audited by BIG 4 Auditor and 0 if audited with other. Of the 30 samples used show the average Quality Audit in 20182014 has a constant value at the value of 0.63 , only in 2014 decreased the average value to reach the figure of 0.56 . The average progress of Audit Quality from public accounting firm ize in 2014 - 2018, appears as follows:

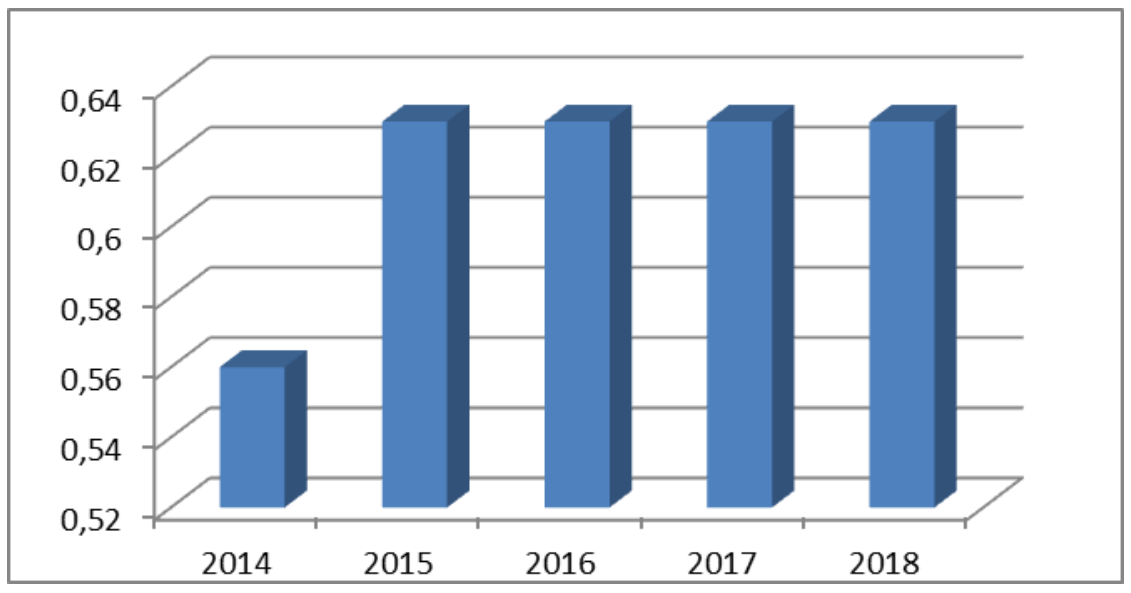

Figure 4 : Composition of the audit committee Chart Year 2014-2018

Source : Data Processed 2019

Earnings management in this research is measured by using De Angelo model formula by using formula DAt $=($ TACt $-\mathrm{NDAt}) /$ TAt. Of the 30 samples used show the average Profit Management in 2018 has a value of 0.165 , in 2017 has an average of -0.004 , in 2016 has an average of 0.226 , the year 2015 has an average value of -0.122 and which last year 2014 has an average value of -0.945 . The average development of Earnings Management in 2014 - 2018, appears

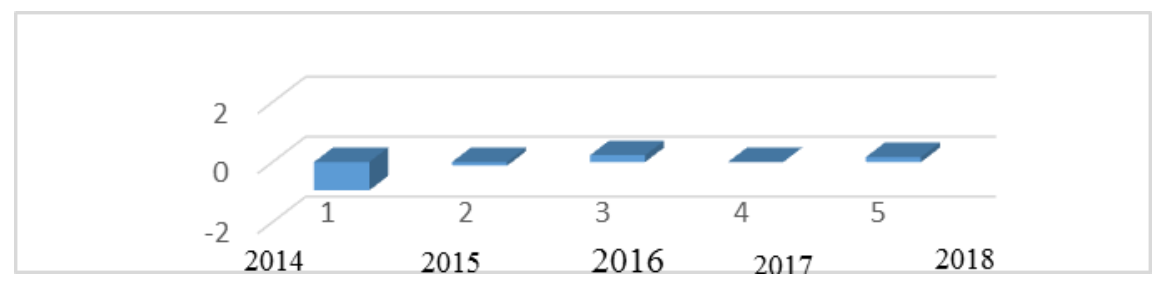

Figure 5 . Earnings Management Chart Year 2014-2018

Source : Data Processed 2019

The simultaneous test is conducted to find out whether all independent variables are managerial composition, composition of board of commissioners, audit committee and audit quality simultaneously have significant effect to earnings management. simultaneous test results (Test F), as follows:

Table 1. Simultaneous test results

\begin{tabular}{llllll}
\hline Model & Sum of Squares & Df & Mean Square & F & Sig. \\
\hline 1 Regression & 2,669 & 4 &, 667 & 17,657 &, $000^{\text {a }}$ \\
Residual & 5,479 & 145 &, 038 & & \\
Total & 8,148 & 149 & & & \\
\hline
\end{tabular}

Source : Data Processed 2019 
Based on the data in table 1 above the test results show the value of Fcount (17.657)> Ftable (2.76) and $p$-value $=0,000<0.05$ means that the independent variables simultaneously have significant effect on the dependent variable. So from the results of $\mathrm{F}$ test, proven simultaneously there is influence between managerial composition, composition of board of commissioner, audit committee composition and audit quality of public accounting firm measure to earnings management at manufacturing company.

Table 2. Partial Test Result

\begin{tabular}{|c|c|c|c|c|c|}
\hline \multirow[b]{2}{*}{ Model } & \multicolumn{2}{|c|}{$\begin{array}{l}\text { Unstandardized } \\
\text { Coefficients }\end{array}$} & $\begin{array}{l}\text { Standardized } \\
\text { Coefficients }\end{array}$ & \multirow{3}{*}{$\begin{array}{l}\mathrm{T} \\
-6,823\end{array}$} & \multirow{3}{*}{$\begin{array}{l}\text { Sig. } \\
, 000\end{array}$} \\
\hline & $\mathrm{B}$ & Std. Error & Beta & & \\
\hline 1 (Constant) &,- 948 & 139 & & & \\
\hline $\begin{array}{l}\text { Managerial } \\
\text { ownership }\end{array}$ & 150 & 074 & 140 & 2,024 & 015 \\
\hline Composition of the & & & & & \\
\hline $\begin{array}{l}\text { Board of } \\
\text { Commissioners }\end{array}$ & ,755 & 173 & 303 & 4,367 & ,000 \\
\hline $\begin{array}{l}\text { Composition of the } \\
\text { audit committee }\end{array}$ & ,762 & 199 & 274 & 3,818 & ,000 \\
\hline $\begin{array}{l}\text { Audit Quality from } \\
\text { public accounting } \\
\text { firm ize }\end{array}$ & 108 & 034 & 231 & 3,205 & ,002 \\
\hline
\end{tabular}

Source : Data Processed 2019

Based on the data in table 2 above, for managerial ownership variable (X1) obtained tcount (2.024) $>$ ttable (2.060) and p-value $=0,015<\alpha$ 0,025 this means managerial ownership (X1) partially positive effect on earnings management. This suggests that increasingly, an increase in managerial ownership will affect the improvement of earnings management. The variable of composition of board of commissioner (X2) obtained by tcount (4,367) $>$ ttable (2.060) and p-value $=0,000<\alpha 0,025$, this also means the composition of the board of commissioners partially positive effect on earnings management which shows that the increasing composition the board of commissioners will influence the improvement of earnings management. Audit committee variables (X3) obtained tcount $(3,818)>$ ttable $(2.060)$ and pvalue $=0,000<\alpha 0,025$, this also means that the audit committee composition partially positively affects earnings management.

This indicates that the composition of the audit committee will affect the improvement of earnings management. The audit quality variable of KAP (X4) size is obtained by tcount (3.205)> ttable (2.060) and p-value $=0.002<\alpha 0.025$, it also means audit quality of KAP size partially positively affect earnings management. This indicates that the increased audit quality of KAP measures will affect the improvement of earnings management.

The results of this test prove that "There is an influence between the managerial composition, the composition of the board of commissioners, the audit committee composition and audit quality of the KAP measure of partially to earnings management of a manufacturing company listed in the Indonesia Stock Exchange year 2014-2018".

From the Partial Test table in the Standardized Coefficients Beta column can be known that the most dominant independent variables affect the dependent variable can be known that variable X2 (Composition of the Board of Commissioners) with the value of Standardized Coefficients Beta 0.303 greater than the value of Standardized Coefficients Beta other independent variables. Thus the established hypothesis proved that "Variable composition of the board of commissioners that dominant influence on earnings management.

Based on the results of research that has been presented in the form of statistics it is necessary to conduct a more in-depth review in order to obtain a more comprehensive picture of this research. The result of hypothesis test by using $\mathrm{F}$ test and significance level $\alpha=5 \%$ indicate independent variable (managerial ownership, composition of board of commissioner, audit committee composition and audit quality from size of Public Accounting Firm simultaneously have significant effect to earnings management at manufacturing company listed in Indonesia Stock Exchange in 2014-2018 where Fhitung $<$ Ftabel $=(17,657<2.76)$ and the significance of the study is greater than $0.05(0.000>0.05)$. 
With such variables Good Corporate Governance consisting of managerial ownership, composition of board of commissioner, audit committee composition, and audit quality from Accountant Firm size can give an explanation about the importance of Good Corporate Governance variable to earnings management. The results of this study are also in line with the results of Boediono's (2005) research that his research shows audit quality, audit committee, managerial ownership, and board composition together positively affect earnings management. However, contrary to research conducted by Trijalmalia (2011).

The result of hypothesis testing by using $t$ test and significance level $\alpha=2.5 \%$ indicates that partially managerial ownership (X1) has significant effect to earnings management at manufacturing companies listed in Indonesia Stock Exchange in 2014-2018. Thus, managerial ownership is assumed to reduce the level of agency problems that arise in a company because the success of Good Corporate Governance is inseparable from the ownership structure. In the variable composition of the board of commissioners (X2) obtained the results that partially this variable significantly influence the earnings management at manufacturing companies listed on the Indonesia Stock Exchange in 2014-2018. The composition of the board of commissioners in the implementation of Good Corporate Governance is the most important part because it is responsible for overseeing all management actions in managing the company including the possibility of management take profit management action.

In the composition of audit committee (X3), it is found that partially this variable has significant effect to earnings management at manufacturing company listed in Indonesia Stock Exchange in 20142018. The audit committee has a very important and strategic role in maintaining the credibility of the financial reporting process so that control of the company will be better and the agency conflict that occurs due to management's desire to improve its own welfare can be minimized. In audit quality variable from Public Accounting Firm (X4) size, it is found that partially this variable also has significant effect to earnings management at manufacturing company listed in Indonesia Stock Exchange in 2014-2018. This may explain that the audit quality of the public accounting firm measure acts as an effective profit management deterrent, since the reputation of management will be destroyed and the firm's value will drop if this false reporting is detected and revealed. It can be explained that any Good Corporate Governance variables are expected to work to suppress or minimize earnings management practices.

The result of this research is also in line with Setiawan's research result (2007) which shows that individually audit committee, audit quality, managerial ownership, composition of board of commissioner have positive effect to earnings management.

From the dominant test results, this study shows that the composition of the board of commissioners most influential partially or the most dominant to earnings management in manufacturing companies listed on the Indonesia Stock Exchange in 2014-2018. The higher the quality of the board of commissioners, the lower the amount of earnings management. The results of this study in accordance with research Setyawan (2009) and Pratiwi (2015) which shows the composition of the board of commissioners most dominant influence on earnings management. But these results contradict the results of research by Hendra J (2018: 7) which shows that company size has a dominant effect on earnings management.

\section{Conclussion}

Based on the research results can be drawn some conclusions as follows: 1) Simultaneously Managerial Ownership, Composition of Board of Commissioners, Composition of Audit Committee and Audit Quality of KAP Size affect on Profit Management. 2) Partially Managerial Ownership, Composition of Board of Commissioners, Composition of Audit Committee, and Audit Quality of KAP Size have positive effect on Profit Management. 3) Variable composition of board of commissioner has the most dominant influence to earnings management as indicated by value of Standardized efficients Beta greater than Standardized Coefficients Beta value of other independent variable. 4) In this study indicates that there are still many companies whose board of commissioners concurrently more than one position.

\section{Reference}

Bapepam. (2004). Peraturan IX.1.5. 2004 tentang Pembentukan dan Pedoman Pelaksanaan Kerja Komite Audit. http://www.bapepamlk.depkeu.go.id

Boediono, G S. B. (2005). Kualitas Laba: Studi Pengaruh Mekanisme Corporate Governance dan Dampak Manajemen Laba dengan Menggunakan Analisa Jalur. Simposium Nasional Akuntansi VIII. Surakarta: Universitas Sebelas Maret. 
Bursa Efek Indonesia (2014). Laporan Keuangan. http://www.idx.co.id

Christiawan, Y. J. dan J. Tarigan. (2007). Kepemilikan Manajerial: Kebijakan Hutang, Kinerja dan Nilai Perusahaan. Jurnal Akuntansi dan Keuangan. Vol. 1. Mei 2007.

Dharmastuti, Christiana Fara (2013). Analisis Pengaruh Mekanisme Internal Dan External Corporate Governance Terhadap Profitabilitas Dan Kebijakan Dividen Perusahaan (Studi Empiris Pada Perusahaan Go Publik Di Pasar Modal Indonesia). Jurnal Organisasi dan Manajemen. Volume 9, Nomor 1. Maret 2013.

Erlina, (2008). Metodologi Penelitian Buku Pedoman Penulisan Skripsi dan Ujian Komprehensif Program Strata Satu (S1), Medan. USU Press, Medan: Fakultas Ekonomi Universitas Sumatera Utara. 2012.

Forum for Corporate Governance in Indonesia. (2001). Peranan Dewan Komisaris dan Komite Audit Dalam Pelaksanaan Corporate Governance (Tata Kelola Perusahaan). www.muhariefeffendi.files.wordpress.com

Gerayli, M., Ma'atofa, S., \& Yane Sari, A.M. (2011). Impact of audit quality on Earnings Management: From Iran. International Research Journal of Finance and Economics. Issue 66. pp. 77-84. www.eurojournals.com/ IRJFE_66_07 in access on 30 October 2011.

Hayati, Annur fitri dan Gusnardi, (2015). Pengaruh Penerapan Mekanisme Good Corporate Governance terhadap Manajemen Laba. Jurnal Akuntansi. Vol. XVI. No. 03: 364-379. September 2012.

Hendra J, Koesharjono, Priantono, (2018). Implication Of Good Corporate Governance And Leverage On Earnings Management. International Journal Of Social Science \& Business. Vol.II No.1: 1-9. http://dx.doi.org/10.23887/ijssb.v2i1.12936 in access on Februari 2018

I Guna, Welvin dan Herawati, Arleen. (2010). Pengaruh Mekanisme Good Corporate Governance, Independensi Auditor, Kualitas Audit dan Faktor Lainnya terhadap Manajemen Laba. Jurnal Bisnis dan Akuntansi. Vol. 12, No. 1: 53-68, April 2010.

Kartika, Nuringsih. (2005). Analisis Pengaruh Kepemilikan Manajerial, Kebijakan Hutang, ROA, dan Ukuran Perusahaan Terhadap Kebijakan Dividen (Pada Perusahaan Manufaktur Di Bursa Efek Indonesia 1995-1996). Jurnal Akuntansi dan Keuangan Indonesia. Vol.2 No.2: 103-123.

Kompas. (2002). Kasus Manajemen Lama. Kompas, 21 November 2012.

Kumala,R. E. (2014). Analisis Pengaruh Mekanisme Good Corporate Governance Terhadap Manajemen Laba (Studi Empiris Pada Perusahaan Jasa Non Keuangan Yang Terdaftar Di Bursa Efek Indonesia Tahun 2010-2012). Skripsi. Semarang: Universitas Diponegoro.

Ma'ruf (2006), Analisis Faktor-Faktor Yang Mempengaruhi Manajemen Laba pada Perusahaan Go-Public di Bursa Efek Jakarta (BEJ). Tesis. Semarang: Universitas Diponegoro.

Nasution, M., dan Setiawan, D.(2007). Pengaruh Corporate Governance Terhadap Manajemen Laba di Industri Perbankan Indonesia. Proceedings Simposium Nasional Akuntansi X Makasar. Hal. 1-26, Juli.

Ningsapiti, Restie. (2010). Analisis Pengaruh Ukuran Perusahaan Dan Mekanisme Corporate Governance Terhadap Manajemen Laba Studi Empiris pada Perusahaan Manufaktur yang terdaftar di Bursa Efek Indonesia 2006-2008, Skripsi. Semarang: Universitas Diponegoro.

Prastiti ,A. (2014). Pengaruh Karakteristik Dewan Komisaris Dan Komite Audit Terhadap Manajemen Laba. Skripsi. Semarang: Universitas Diponegoro

Pratiwi, F. L. (2015). Analisis Mekanisme Good Corporate Governance Terhadap Manajemen Laba Pada Perusahaan Manufaktur yang Terdaftar di BEI. Jurnal Riset Mahasiswa Akuntansi. ISSN: 2337-56xx. Vol.xx No.xx 
Priyatno, Dwi. (2008). Mandiri Belajar SPSS Untuk Analisis Data \& Uji Statistik. Jakarta: MediaKom.

Pujiati. (2015). Pengaruh Kepemilikan Manajerial, Kepemilikan Institusional, Dan Kesempatan Investasi Terhadap Kebijakan Dividen Dengan Likuiditas Sebagai Variabel Pemoderasi (Studi Empiris Pada Perusahaan Sektor Industri Barang Konsumsi Yang Terdaftar Di Bursa Efek Indonesia Periode (20082013). Skripsi. Yogyakarta: Universitas Negeri Yogyakarta

Puspitasari, F. dan Ernawati E. (2010). Pengaruh Mekanisme Corporate Governance Terhadap Kinerja Keuangan Badan Usaha. Jurnal Manajemen Teori dan Terapan. Vol. 3. No. 2: 189-215. Agustus 2010

Qomariyah, Tri Listiani. (2008). Analisis Pengaruh Ukuran Perusahaan dan Praktek Coeporate Governance terhadap Pengelolaan Laba, Skripsi. Universitas Islam Negeri Sunan Kalijaga.

Retno, M dan Denies Priantinah. (20120. Pengaruh Good Corporate Governance dan Pengungkapan Corporate Social Responsibility Terhadap Nilai Perusahaan (Studi Empiris Pada Perusahaan yang Terdaftar di Bursa Efek Indonesia Periode 2007-2010). Jurnal Nominal. Vol. 1 No. 1

Sangadji, E. M. dan Sopiah. (2010). Metodologi Penelitian; Pendekatan Praktis dalam Penelitian. Yogyakarta: CV Andi Offset.

Setiawan, Teguh. (2009). Analisis Pengaruh Mekanisme Good Corporate Governance Terhadap Praktek Manajemen Laba Pada Perusahaan Manufaktur yang terdaftar di Bursa Efek Indonesia Periode 20052007. Jurnal Akuntansi Kontemporer. Vol. 1. N0. 2. Juli 2009.

Subramanyam dan Wild, (2010). Analisis Laporan Keuangan. Buku Satu, Edisi Kesepuluh, Jakarta: Salemba Empat.

Sulistyanto, Sri. (2008). Manajemen Laba: Teori dan Empiris. Jakarta: PT. Gramedia

Surya, I. dan Yustiavandana I. (2006). Penerapan Good Corporate Governance: Mengesampingkan Hak Istimewa Demi Kelangsungan Usaha. Jakarta: Prenada Media Group. 